Journal Club

Editor's Note: These short reviews of recent JNeurosci articles, written exclusively by students or postdoctoral fellows, summarize the important findings of the paper and provide additional insight and commentary. If We of the highlighted article have written a response to the Journal Club, the response can be found by viewing the Journal Club at www.jneurosci.org. For more information on the format, review process, and purpose of Journal Club articles, please see http://jneurosci.org/content/ preparing-manuscript\#journalclub.

\title{
Cereblon Regulates BK Channel Expression at Presynaptic and Postsynaptic Sites in Excitatory Synapses
}

\author{
Alberto J. Gonzalez-Hernandez, ${ }^{1,2}$ Laura E. Maglio, ${ }^{1,2}$ and ${ }^{\odot R i c a r d o ~ G o ́ m e z ~}{ }^{1,2}$ \\ ${ }^{1}$ Departamento de Ciencias Médicas Básicas (Área de Fisiología), Facultad de Medicina, and ${ }^{2}$ Instituto de Tecnologías Biomédicas (ITB), Universidad de La \\ Laguna, 38071 Tenerife, Spain \\ Review of Choi et al.
}

Cereblon is a substrate receptor protein for the CRL4A E3 ubiquitin ligase complex. As such, cereblon binds to different proteins to promote their ubiquitination and degradation (Zheng and Shabek, 2017). Cereblon is highly expressed in brain tissues, including the hippocampus, cortex, cerebellum, and striatum (Higgins et al., 2010; Aizawa et al., 2011). Missense mutations of this protein and deletion or microduplication of the chromosomal segment harboring the Cereblon gene have been linked to human intellectual disability (Higgins et al., 2004; Dijkhuizen et al., 2006; Papuc et al., 2015).

To elucidate how cereblon mutations might lead to intellectual disability, Choi et al. (2018) studied behavior and synaptic function in mice lacking or expressing mutated forms of cereblon. Macroscopic brain architecture and dendritic spine morphology were similar in wild-type and

Received May 30, 2018; revised Aug. 3, 2018; accepted Aug. 8, 2018.

A.J.G.-H. was supported by Spanish Ministerio de Educación, Cultura y Deporte Predoctoral Fellowship FPU15/02528. L.E.M. and R.G. were supported by European Research Council Postdoctoral Contracts, under Horizon 2020 Research and Innovation Programme Grant 648936. We thank Dr. Teresa Giráldez for providing feedback during the preparation of the manuscript.

The authors declare no competing financial interests.

Correspondence should be addressed to Dr. Ricardo Gómez, Departamento de Ciencias Médicas Básicas (Área de Fisiología), Facultad de Medicina, Universidad de La Laguna, Campus de Ofra s/n, 38071 La Laguna, Tenerife, Spain. E-mail: rgomezga@ull.edu.es.

DOI:10.1523/JNEUROSCI.1402-18.2018

Copyright $\odot 2018$ the authors $\quad 0270-6474 / 18 / 387932-03 \$ 15.00 / 0$ cereblon-null animals. Furthermore, no apparent differences were found in spontaneous synaptic transmission or longterm synaptic plasticity after cereblon deletion. Similar results were found in Drosophila. In contrast, lack of cereblon led to a reduction in the amplitude of evoked excitatory synaptic transmission (eEPSC). Furthermore, mice lacking cereblon performed abnormally in passive avoidance and novel object recognition tests. These results suggest that loss of cereblon impairs cognitive function by reducing presynaptic glutamate release probability.

The probability of glutamate release from presynaptic terminals was assessed by computing the paired-pulse ratio: the relative amplitude of postsynaptic responses elicited by two presynaptic spikes (second response/first response). This ratio was increased, suggesting release probability was reduced after cereblon knock-out in both species. This presynaptic impairment was also present in animals expressing mutant forms of cereblon that mimic mutations related to mild intellectual disability in humans, namely, the R419X cereblon mutant in mice and the G552X mutant in Drosophila. A similar decrease in glutamate release was suggested by experiments involving a short-term synaptic plasticity protocol consisting of 20-pulse train stimulation: the amplitude of successive eEPSCs in- creased in cereblon-null mice, suggesting a presynaptic origin of the impairment.

As part of the CRL4A E3 ubiquitin ligase complex, cereblon regulates the trafficking and plasma membrane expression of the large-conductance $\mathrm{Ca}^{2+}$-activated $\mathrm{K}^{+}$channel (BK) $\alpha$ subunit (Jo et al., 2005; Liu et al., 2014). BK channels are thought to be key regulators of neurotransmitter release in many synapses (for review, see Griguoli et al., 2016). Therefore, Choi et al. (2018) studied whether the reduction in neurotransmitter release in cereblon-null animals resulted from modifications in BK function and/or channel expression levels. Total expression levels of BK channels in hippocampal CA1 pyramidal neurons were unaffected by cereblon knock-out, but surface expression and the amplitude of BK-mediated currents were increased. Furthermore, blocking $\mathrm{BK}$ currents restored glutamate release probability to wild-type levels and rescued abnormal cognitive behaviors in cereblon-null animals.

Choi et al. (2018) present clear evidence that loss of cereblon impairs cognitive function by increasing surface expression of BK channels and reducing presynaptic glutamate release probability in excitatory synapses. However, how these effects are linked remains unclear. Because BK channels are expressed at both presynaptic and postsynaptic synaptic terminals, as well as in the soma of multiple cellular types in the central nervous system (Latorre et 
al., 2017), mutations disrupting surface expression of BK channels at any of these locations might impair synaptic transmission.

At presynaptic active zones, BK channels coassemble with voltage-gated $\mathrm{Ca}^{2+}$ channels (VGCCs) (Grunnet and Kaufmann, 2004; Berkefeld et al., 2006). Opening of VGCCs produces the $\mathrm{Ca}^{2+}$ influx necessary for BK activation, which in turn repolarizes the presynaptic terminal, curtailing the opening of VGCCs and thus terminating $\mathrm{Ca}^{2+}$ influx and neurotransmitter release. Therefore, the increase in BK function occurring after cereblon deletion would be expected to reduce $\mathrm{Ca}^{2+}$ influx at the presynaptic terminal, thus reducing release probability. BK blockers would abolish this "brake" in VGCCdependent $\mathrm{Ca}^{2+}$ influx, increasing glutamate release. However, this model is difficult to reconcile with previous results demonstrating that $\mathrm{BK}$ channels do not modulate transmitter release under basal conditions or during high-frequency stimulation in hippocampal CA3-CA1 synapses (Hu et al., 2001). The model is also inconsistent with results demonstrating that mutations disrupting the BK channel orthologue encoded by the slowpoke gene have little effect on glutamate release in Drosophila neuromuscular junction (Lee et al., 2008). An alternative model to explain the effects of cereblon deletion on glutamate release is that cereblon modulates $\mathrm{BK}$ channels at the soma of the presynaptic cell.

Somatic BK channels play a pivotal role in modulating action potential shape and frequency (Sailer et al., 2006), with inhibition of BK channels leading to either an increase or a decrease in action potential firing (Latorre et al., 2017). In hippocampal CA3 pyramidal neurons (the presynaptic cells in the mouse experiments by Choi et al., 2018), a decrease in BK channel activity is associated with a broadening of action potential duration and an increase in glutamate release, a situation that was reversed using a BK channel blocker (Deng et al., 2013). Conversely, the increase in BK channel function described by Choi et al. (2018) would be expected to shorten the action potential duration in CA3 pyramidal neurons, causing a decrease in glutamate release; the subsequent application of a BK channel blocker would then abolish this decrease, as described in the article.

Finally, some results in the work by Choi et al. (2018) cannot be explained without taking into account possible roles of postsynaptic BK channels. Indeed, the authors measured BK current amplitude only in CA1 pyramidal neurons, the postsynaptic cells in their experiments. In postsynaptic cells, BK channels are often located in close proximity with postsynaptic proteins, such as PSD95 and NMDA receptors (NMDARs). Indeed, a functional coupling between NMDAR and BK channels has been described in olfactory bulb granule cells (Isaacson and Murphy, 2001). In this context, an increase in BK channel expression/function would reduce the influx through NMDAR at the postsynaptic terminals in a similar way to what has been described for VGCC-BK association: $\mathrm{Ca}^{2+}$ influx through NMDAR would be enough to produce BK activation, thus repolarizing the postsynaptic terminal and terminating NMDARdependent $\mathrm{Na}^{+}$and $\mathrm{Ca}^{2+}$ influx. Consistent with this mechanism, a decrease in the amplitude of the eEPSCs (due to both AMPA and NMDA receptors) was observed (Choi et al., 2018, their Fig. $2 A$ ), without any modification of the spontaneous EPSC (mainly due to AMPA receptors) (Choi et al., 2018, their Fig. $2 B$ ). This could also explain why eEPSCs were reduced in mice, whereas Drosophila excitatory junction currents were unaffected in cereblondeficient animals, given that glutamatergic postsynaptic receptors at the Drosophila neuromuscular junction (DGluRIIA and DGluRIIB) are homologous to vertebrate AMPA and kainate receptors (Petersen et al., 1997; Davis et al., 1998). An inhibitory effect of BK on NMDAR could also be presumed from the current traces of EPSCs recorded from cereblon knock-out mice because the decay kinetics are slightly accelerated compared with wild-type (e.g., Choi et al., 2018, their Fig. 2C), as they would be if NMDAR-driven currents were inhibited.

In conclusion, the work by Choi et al. (2018) highlights the importance of BK channels on synaptic excitability, specifically related to their location. Undoubtedly, these results open a new and exciting avenue for research. In particular, future work should address the extent to which presynaptic and postsynaptic BK channels contribute to altered synaptic transmission and cognitive defects. More broadly, BK channels might be a promising pharmacological target in the search for new ways of treating intellectual disabilities.

\section{References}

Aizawa $\mathrm{M}$, Abe $\mathrm{Y}$, Ito $\mathrm{T}$, Handa $\mathrm{H}$, Nawa $\mathrm{H}$ (2011) mRNA distribution of the thalido- mide binding protein cereblon in adult mouse brain. Neurosci Res 69:343-347. CrossRef Medline

Berkefeld H, Sailer CA, Bildl W, Rohde V, Thumfart JO, Eble S, Klugbauer N, Reisinger E, Bischofberger J, Oliver D, Knaus HG, Schulte U, Fakler B (2006) BKCa-Cav channel complexes mediate rapid and localized $\mathrm{Ca}^{2+}$ activated $\mathrm{K}^{+}$signaling. Science 314:615-620. CrossRef Medline

Choi TY, Lee SH, Kim YJ, Bae JR, Lee KM, Jo Y, Kim SJ, Lee AR, Choi S, Choi LM, Bang S, Song MR, Chung J, Lee KJ, Kim SH, Park CS, Choi SY (2018) Cereblon maintains synaptic and cognitive function by regulating $\mathrm{BK}$ channel. J Neurosci 38:3571-3583. CrossRef Medline

Davis GW, DiAntonio A, Petersen SA, Goodman CS (1998) Postsynaptic PKA controls quantal size and reveals a retrograde signal that regulates presynaptic transmitter release in Drosophila. Neuron 20:305-315. CrossRef Medline

Deng PY, Rotman Z, Blundon JA, Cho Y, Cui J, Cavalli V, Zakharenko SS, Klyachko VA (2013) FMRP regulates neurotransmitter release and synaptic information transmission by modulating action potential duration via BK channels. Neuron 77:696-711. CrossRef Medline

Dijkhuizen T, van Essen T, van der Vlies P, Verheij JB, Sikkema-Raddatz B, van der Veen AY, Gerssen-Schoorl KB, Buys CH, Kok K (2006) FISH and array-CGH analysis of a complex chromosome 3 aberration suggests that loss of CNTN4 and CRBN contributes to mental retardation in 3pter deletions. Am J Med Genet A 140:2482-2487. CrossRef Medline

Griguoli M, Sgritta M, Cherubini E (2016) Presynaptic BK channels control transmitter release: Physiological relevance and potential therapeutic implications. J Physiol 594:34893500. CrossRef Medline

Grunnet M, Kaufmann WA (2004) Coassembly of big conductance $\mathrm{Ca}^{2+}$-activated $\mathrm{K}^{+}$channels and L-type voltage-gated $\mathrm{Ca}^{2+}$ channels in rat brain. J Biol Chem 279:36445-36453. CrossRef Medline

Higgins JJ, Pucilowska J, Lombardi RQ, Rooney JP (2004) A mutation in a novel ATPdependent Lon protease gene in a kindred with mild mental retardation. Neurology 63: 1927-1931. CrossRef Medline

Higgins JJ, Tal AL, Sun X, Hauck SC, Hao J, Kosofosky BE, Rajadhyaksha AM (2010) Temporal and spatial mouse brain expression of cereblon, an ionic channel regulator involved in human intelligence. J Neurogenet 24:1826. CrossRef Medline

Hu H, Shao LR, Chavoshy S, Gu N, Trieb M, Behrens R, Laake P, Pongs O, Knaus HG, Ottersen OP, Storm JF (2001) Presynaptic $\mathrm{Ca}^{2+}$ activated $\mathrm{K}^{+}$channels in glutamatergic hippocampal terminals and their role in spike repolarization and regulation of transmitter release. J Neurosci 21:9585-9597. CrossRef Medline

Isaacson JS, Murphy GJ (2001) Glutamatemediated extrasynaptic inhibition: Direct coupling of NMDA receptors to $\mathrm{Ca}^{2+}$. activated $\mathrm{K}^{+}$channels. Neuron 31:10271034. CrossRef Medline

Jo S, Lee KH, Song S, Jung YK, Park CS (2005) 
Identification and functional characterization of cereblon as a binding protein for largeconductance calcium-activated potassium channel in rat brain. J Neurochem 94:12121224. CrossRef Medline

Latorre R, Castillo K, Carrasquel-Ursulaez W, Sepulveda RV, Gonzalez-Nilo F, Gonzalez C, Alvarez O (2017) Molecular determinants of BK channel functional diversity and functioning. Physiol Rev 97:39-87. CrossRef Medline

Lee J, Ueda A, Wu CF (2008) Pre- and postsynaptic mechanisms of synaptic strength homeostasis revealed by slowpoke and shaker
$\mathrm{K}^{+}$channel mutations in Drosophila. Neuroscience 154:1283-1296. CrossRef Medline

Liu J, Ye J, Zou X, Xu Z, Feng Y, Zou X, Chen Z, Li Y, Cang Y (2014) CRL4A(CRBN) E3 ubiquitin ligase restricts $\mathrm{BK}$ channel activity and prevents epileptogenesis. Nat Commun 5:3924. CrossRef Medline

Papuc SM, Hackmann K, Andrieux J, VincentDelorme C, Budisteanu M, Arghir A, Schrock E, Tutulan-Cunita AC, Di Donato N (2015) Microduplications of 3p26.3p26.2 containing CRBN gene in patients with intellectual disability and behavior abnormalities. Eur J Med Genet 58:319-323. CrossRef Medline
Petersen SA, Fetter RD, Noordermeer JN, Goodman CS, DiAntonio A (1997) Genetic analysis of glutamate receptors in Drosophila reveals a retrograde signal regulating presynaptic transmitter release. Neuron 19:12371248. CrossRef Medline

Sailer CA, Kaufmann WA, Kogler M, Chen L, Sausbier U, Ottersen OP, Ruth P, Shipston MJ, Knaus HG (2006) Immunolocalization of BK channels in hippocampal pyramidal neurons. Eur J Neurosci 24:442-454. CrossRef Medline

Zheng N, Shabek N (2017) Ubiquitin ligases: Structure, function, and regulation. Annu Rev Biochem 86:129-157. CrossRef Medline 